\title{
PENGUJIAN JARAK JANGKAUAN KOMUNIKASI RF DARI PANEL KONTROL TERHADAP MOBIL LISTRIK AUTRON POLINEMA
}

\author{
Moch Irfan Rahman ${ }^{1)}$, Fatkhur Rohman ${ }^{2)}$ \\ ${ }^{1)}$ Mahasiswa Program Studi Teknik Otomotif Elektronik Politeknik Negeri Malang \\ ${ }^{2)}$ Dosen Program Studi Teknik Otomotif Elektronik Politeknik Negeri Malang \\ 1)ir2914019@gmail.com \\ ${ }^{2)}$ fatkhur rohman@polinema.ac.id
}

\begin{abstract}
Abstrak
Permasalahan jarak komunikasi tanpa kabel antara remote dan mobil mainan anak dengan jarak yang pendek. Dari jarak komunikasi yang pendek, membandingkan komunikasi nirkabel antara infrared dan RF. Dari dua peneltian sebelumnya memaparkan bahwa komunikasi RF menjadi solusi untuk memberikan jarak jangkuan yang jauh. Tujuan penelitian ini adalah untuk mengetahui cara mengirim data perintah kendali mobil listrik Autron Polinema melalui transmisi nirkabel RF dan memngetahui cara menguji kerja transmisi nirkabel RF. Selain itu, Penelitian ini juga menguji jarak dan halangan pada modul RF yang digunakan untuk mengambil data yang telah didapatkan. Modul RF ini menggunkan LoRa Ra-01 dengan jarak jangkuan hingga $10 \mathrm{KM}$. Metode penelitian ini adalah menguji dependent variable pada independent variable. Dependent variable (variabel tetap) ditentukan dari modul RF yang diuji dengan jarak $10 \mathrm{KM}$ (Kilometer) sesuai datasheet. Independent variable (variable bebas) ditentukan dengan pengujian pada daerah halangan sepi, sedang, dan ramai. Hasil penelitian ini adalah komunikasi 2 transmisi RF yaitu pengirim (transmitter) mengirim 2 jenis paket pada penerima (receiver) yang dibaca pada aplikasi PuTTY. Pengujian kerja modul RF pada halangan sepi, sedang, dan ramai menunjukan semakin panjang jarak komunikasi semakin lemah sinyal dan semakin banyak halangan semakin lemah sinyal.Kata-kata kunci: sensor laser scanner, autonomous, kendaraan, kecelakaan lalu lintas.
\end{abstract}

Kata Kunci: Halangan, Komunikasi RF, LoRa Ra-01, dan Sinyal.

\section{PENDAHULUAN}

Permasalahn jarak komunikasi tanpa kabel antara remote dan mobil mainan anak sampai sekarang masih dibatasi 10 meter. Dengan jarak komunikasi 10 meter yang pendek membuat pengendali (remote) harus bergerak mendekati mobil mainan anak untuk dapat dikendalikan lagi. Selain itu, pengendali tidak bisa memantau dari jarak komunikasi yang jauh. Infrared digunakan untuk pengendalian jarak komunikasi tanpa kabel yaitu pada remote TV, AC, dll. (Muchlas, Anton, dkk. 2005) menjelaskan dalam artikelnya bahwa prinsip kerja infrared menggunakan LED (light emitting diode) untuk mengirimkan suatu isyarat IR (infrared) sebagai tanggapan dari penekanan tombol pada remote control (TV, AC, dll). Pengaturan jarak jauh dengan infrared memiliki kelebihan, diantaranya bebas noise, tidak terganggu oleh sistem komunikasi, murah dan peralatan lebih sederhana. Salah satu kekurangan dari infrared ialah tidak dapat menembus halangan. Selain infrared pengendali jarak komunikasi tanpa kabel ialah RF (radio frequency). (Grace dan Boby. 2013) menjelaskan pada jurnal bahwa RF (radio frequency) adalah sebuah sinyal arus bolak-balik dengan frekuensi tinggi yang berkomunikasi pada pancaran ke udara melalui suatu antena. Kelebihan dari RF, dapat berkomunikasi hingga 50 meter dengan menembus halangan. Namun kekurangan dari RF ialah harganya yang relatif mahal. Dari dua macam komunikasi diatas, kita dapat mengetahui komunikasi mana yang dapat memberikan jarak yang jauh antara remote dan mobil mainan anak yaitu RF (radio frequency). Namun dari penelitian diatas, kita belum mengetahui berapa beras frequency yang dibutuhkan untuk pengendali jarak jauh atau sesuai dengan 
yang kita inginkan. Sehingga penelitian ini akan menguji jarak jangkuan dengan menggunakan komunikasi RF (radio frequency).

Sensor RF (Radio Frekuensi) merupakan komponen yang dapat mendeteksi sinyal gelombang elektromagnetik yang digunakan oleh sistem komunikasi untuk mengirim informasi melalui udara dari satu titik ke titik lainnya yang merambat di antara antena pemancar pengirim dan penerima. (Nindya Armadeta, 2016).

Ra-01 adalah salah satu modul RF yang digunakan untuk komunikasi nirkabel. Ra-01 dapat digunakan untuk komunikasi spektrum penyebaran jarak jauh, (AiThinker Ra-01 LoRa).

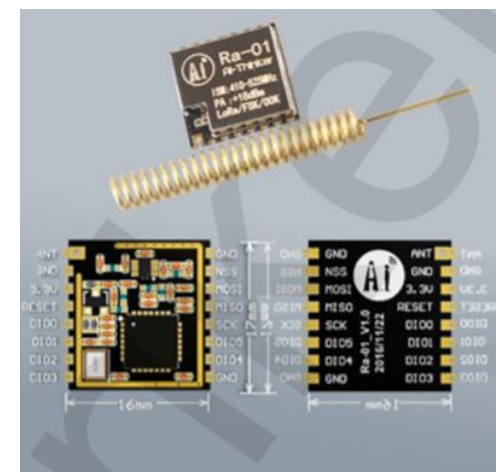

Gambar 1. LoRa Ra-01

(Ai-Thinker Ra-01 LoRa Product Specification)

Arduino Uno adalah suatu minsis yang digunakan untuk menanam programan dengan menggunakan ATMega328. Papan elektornik ini dapat digunakan untuk mewujudkan rangkaian program sederhana hingga yang rumit. (Widya Hurisantri, 2016).

PuTTY adalah sebuah software yang dapat digunakan untuk melakukan portokol jaringan SSH, Telnet, dan Rlogin. Protokol ini digunakan untuk menjalankan sesi remote pada komputer melalui sebuah jaringan, baik itu LAN atau USB untuk menunjukan PORT yang digunakan. (Ade, 2015).

\section{METODOLOGI PENELITIAN}

Pengambilan data dilakukan dengan menentukan variable bebas yang digunakan dalam pengambilan dan pengujian data yaitu dengan memvarisi jarak pandang mata terhadap halangan sepi (Atap Gedung Sipil - Perum BTU), sedang (Pom Bensin Ciliwung - Pabrik Nevia (Mondoroko)), ramai (POM Bensin Ciliwiung - Jalan Raya Slamet (Masjid Darusallam)). Dan Pada variabel terikat penelitian ini menggunakan jarak jangkuan yang dilihat pengukuran. Sehingga hasil tersebut dapat dianalisa jarak jangkuan yang dapat ditempuh dengan menggunakan LoRa Ra-01 yaitu mulai jarak $0-10 \mathrm{Km}$.

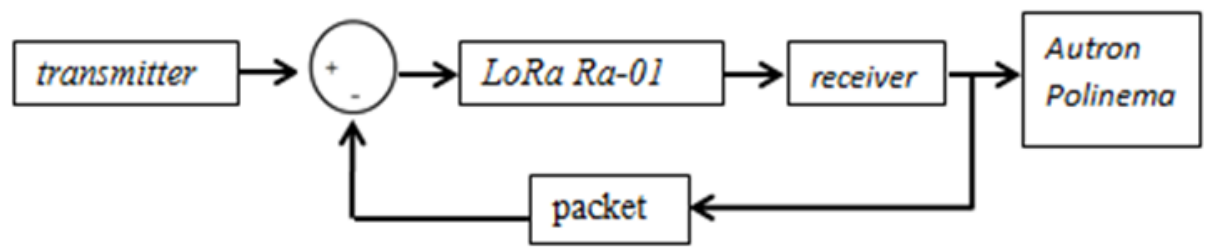

Gambar 2. Diagram Komunikasi RF 


\section{HASIL DAN PEMBAHASAN}

Pengambilan data dilakukan berdasarkan metode penelitian yang telah tercantumkan di metodolgi dan data diambil di daerah yang sudah ditentukan dengan variabel yang telah di tentukan sebelumnya. Adapun data yang telah di peroleh ialah sebagai berikut:

Tabel 1. Pengujian pada Halangan Sepi

\begin{tabular}{|l|l|l|l|}
\hline \multirow{2}{*}{ Jarak $(\mathrm{m})$} & \multicolumn{2}{|c|}{ Sinyal (db) } & \multirow{2}{*}{$\begin{array}{c}\text { Range } \\
\text { sinyal }\end{array}$} \\
\cline { 2 - 3 } & Besar & \multicolumn{1}{|c|}{ Kecil } & \\
\hline $0-100$ & -29 & -90 & 62 \\
\hline $100-200$ & -77 & -117 & 40 \\
\hline $200-300$ & -110 & -124 & 14 \\
\hline $300-400$ & -106 & -123 & 17 \\
\hline $400-500$ & -112 & -124 & 12 \\
\hline $500-8000$ & & & 0 \\
\hline $8000-8100$ & -112 & -124 & 12 \\
\hline $8100-10000$ & & & 0 \\
\hline
\end{tabular}

Tabel 2. Pengujian pada Halangan Sedang

\begin{tabular}{|l|l|l|l|}
\hline \multirow{2}{*}{ Jarak $(\mathrm{m})$} & \multicolumn{2}{c|}{ Sinyal $(\mathrm{db})$} & \multirow{2}{*}{$\begin{array}{c}\text { Range } \\
\text { sinyal }\end{array}$} \\
\cline { 2 - 3 } & Besar & Kecil & \multicolumn{1}{c|}{} \\
\hline $0-100$ & -29 & -89 & 61 \\
\hline $100-200$ & -72 & -85 & 13 \\
\hline $200-300$ & -91 & -117 & 26 \\
\hline $300-400$ & -106 & -118 & 12 \\
\hline $400-500$ & -104 & -120 & 16 \\
\hline $500-600$ & -103 & -120 & 17 \\
\hline $600-700$ & -110 & -121 & 11 \\
\hline $700-800$ & -104 & -124 & 20 \\
\hline $800-900$ & -118 & -123 & 5 \\
\hline $900-10000$ & & & 0 \\
\hline
\end{tabular}

Tabel 3. Pengujian pada Halangan Ramai

\begin{tabular}{|l|l|l|l|}
\hline \multirow{2}{*}{ Jarak $(m)$} & \multicolumn{2}{c|}{ Sinyal $(\mathrm{db})$} & \multirow{2}{*}{$\begin{array}{c}\text { Range } \\
\text { sinyal }\end{array}$} \\
\cline { 2 - 3 } & Besar & Kecil & \multirow{2}{*}{. } \\
\hline $0-100$ & -29 & -118 & 88 \\
\hline $100-200$ & -115 & -124 & 10 \\
\hline $200-10000$ & & & 0 \\
\hline
\end{tabular}




\section{KESIMPULAN}

Dari hasil pengujian kerja transmmisi RF adalah melemahnya sinyal dipengaruhi oleh jarak jangkuan jauh dan banyak halangan.

\section{DAFTAR PUSTAKA}

Atmadera, Nindya. 2016. Rancangan Bangun Pengendalu Tirai Vertical Blind dengan Menggunkan Gelombang Radio $(R F)$. Politeknik Negeri Sriwijaya.

Apriyatna, GP Ade. 2015. Aplikasi Computer Server dan Clustering dengan Simulasi Virtual Box pada PDAM Kota Surabaya. STIKOM Surabaya.

Muchlas., Anton Yudhana., Sigit Wijaya. Tranceiver Infra Merah Termodulasi untuk Pengendalian Alat-Alat Listrik. Universitas Ahmad Dahlan.

Usmany, Grace G.P., Bobi K.S. 2013. Studi Komparasi Beberapa Strategi Pengontrolan Peralatan Elektronik Rumah Tangga secara Nirkabel. UNIKOM Bandung 